\title{
AUDIT TEKNOLOGI INFORMASI \\ REVIEW ARTIKEL ILMIAH METODE ISO 38500
}

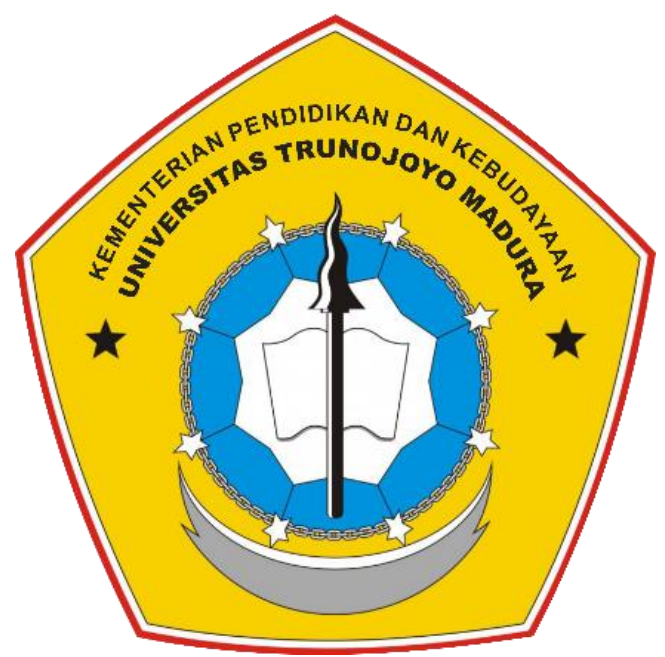

Disusun Oleh:

M Agiel Asy’ari

170441100033

Abdur Rouf

170441100037

Dosen Pengampu: Shofia Hardi, S.Kom., M.T.

PROGRAM STUDI S1 SISTEM INFORMASI

JURUSAN TEKNIK INFORMATIKA

FAKULTAS TEKNIK

UNIVERSITAS TRUNOJOYO MADURA

2020 


\title{
AUDIT TEKNOLOGI INFORMASI REVIEW ARTIKEL ILMIAH METODE ISO 38500
}

\author{
Muhammad Agiel Asy'ari ${ }^{1}$, Abdur Rouf ${ }^{2}$ \\ ${ }^{1,2}$ Program Studi Sistem Informasi, Universitas Trunojoyo Madura \\ E-Mail: 170441100033@student.trunojoyo.ac.id ${ }^{1}$, \\ 170441100037@student.trunojoyo.ac.id ${ }^{2}$
}

\begin{abstract}
Abstrak
Perusahaan semakin meningkatkan kinerja TI untuk mendorong pertumbuhan bisnis, mendapatkan keunggulan kompetitif, dan memungkinkan diferensiasi strategis, manajemen dan tata kelola TI. Kondisi tersebut semakin penting karena semakin kompleksnya organisasi bisnis serta sistem dan teknologi. Audit teknologi informasi membutuhkan kerangka kerja yang didasarkan pada prinsip dan persyaratan akuntabilitas yang mendorong perilaku yang diinginkan dalam penerapan dan penggunaan teknologi. Dalam laporan ini, kami mengulas penggunaan metode ISO 38500 sebagai standar internasional untuk tata kelola perusahaan teknologi informasi dan komunikasi, untuk menunjukkan bagaimana tata kelola TI dapat dicapai dengan menggunakan prinsip-prinsip ISO 38500. Ulasan ini dapat menambah wawasan mengenai audit teknologi informasi menggunakan ISO 38500 .
\end{abstract}

Kata Kunci: Audit, Teknologi Informasi, ISO 38500 


\section{PENDAHULUAN}

Perusahaan semakin meningkatkan kinerja TI untuk mendorong pertumbuhan bisnis, mendapatkan keunggulan kompetitif, dan memungkinkan diferensiasi strategis, manajemen dan tata kelola TI. Kondisi tersebut semakin penting karena semakin kompleksnya organisasi bisnis serta sistem dan teknologi. Dalam skenario yang sedemikian kompleks, salah satu tantangan terbesar bagi organisasi TI adalah perlindungan aset informasi, pencegahan pencurian kekayaan intelektual, dan menjaga privasi karyawan dan pelanggan.

Audit teknologi informasi membutuhkan kerangka kerja yang didasarkan pada prinsip dan persyaratan akuntabilitas yang mendorong perilaku yang diinginkan dalam penerapan dan penggunaan teknologi. Ini melibatkan kerangka kerja yang mendukung struktur dan proses manajemen untuk memberikan jaminan bahwa strategi bisnis diselaraskan dengan dan mendukung tujuan bisnis, konsisten dengan hukum dan peraturan melalui kepatuhan terhadap kebijakan dan kontrol internal, memberikan penugasan tanggung jawab kepada semua untuk mengelola risiko. Karenanya, kerangka tata kelola keamanan TI apa pun harus mencakup komponen penyelarasan, kepatuhan, dan akuntabilitas.

Dalam laporan ini, kami mengulas penggunaan metode ISO 38500 sebagai standar internasional untuk tata kelola perusahaan teknologi informasi dan komunikasi, untuk menunjukkan bagaimana tata kelola TI dapat dicapai dengan menggunakan prinsip-prinsip ISO 38500. Makalah ini menarik perhatian pada aspek tata kelola dengan menggunakan ISO 38500 yang diakui secara internasional untuk tata kelola TI dan menunjukkan bagaimana metode ini dapat dimanfaatkan untuk mencapai tata kelola TI yang baik.

\section{KAJIAN PUSTAKA}

\subsection{Audit Teknologi Informasi}

Audit teknologi informasi (Inggris: information technology (IT) audit atau information systems (IS) audit) adalah bentuk pengawasan dan pengendalian dari infrastruktur teknologi informasi secara menyeluruh. Audit teknologi informasi ini dapat berjalan bersama-sama dengan audit 
finansial dan audit internal, atau dengan kegiatan pengawasan dan evaluasi lain yang sejenis.

Tujuan Audit Teknologi Informasi adalah untuk mengevaluasi desain pengendalian internal sistem dan efektivitas. Dalam lingkungan Sistem Informasi (SI), audit adalah pemeriksaan sistem informasi, input, output, dan pengolahan. Fungsi utama audit TI ini adalah mengevaluasi sistem untuk menjaga keamanan data organisasi.

\subsection{ISO 38500}

ISO 38500 adalah standar internasional untuk tata kelola TI. Ini menetapkan enam prinsip tata kelola perusahaan yang baik dari IT yang mengungkapkan perilaku yang disukai untuk memandu pengambilan keputusan dan tanggung jawab, strategi, akuisisi, kinerja, kesesuaian, dan perilaku manusia. ISO 38500 merekomendasikan bahwa:

a. Rencana dan kebijakan harus ditetapkan di tingkat perusahaan untuk memandu proyek-proyek TI.

b. Proposal untuk perbaikan TI dan usaha baru harus berasal dari tingkat proyek dan operasional, tetapi harus dilaporkan untuk evaluasi kepada manajemen perusahaan.

c. Kinerja dan kesesuaian proyek-proyek TI adalah tanggung jawab dewan perusahaan.

d. Kebutuhan bisnis harus secara jelas diidentifikasi dan dievaluasi untuk setiap proyek TI.

e. Dewan perusahaan bertanggung jawab untuk pengarahan, evaluasi, dan pemantauan semua entitas TI.

\section{METODE PENELITIAN}

Dalam laporan ini menggunakan metode studi literatur yang digunakan untuk pembelajaran dan pemahaman informasi yang terkait dengan pokok pembahasan metode ISO 38500. Literatur yang digunakan dalam pembahasan ini didapatkan dari berbagai sumber seperti literatur digital, dan artikel jurnal penelitian. Metode pengumpulan data dalam laporan ini diperoleh melalui 
observasi dan pembahasan analisis terhadap implementasi metode ISO 38500 yang sudah ada sebelumnya. Analisis ini nantinya dapat diperoleh data-data yang memiliki relevansi pada topik review yang dilakukan.

\section{PEMBAHASAN}

Penelitian yang dilakukan oleh Suchit Ahuja dan Yolande E. Chan dari Queen's School of Business Queen's University, Kingston, Canada, pada tahun 2015 yang berjudul "IT Security Governance: A Framework based on ISO 38500" memperoleh hasil bahwa menggabungkan komponen ISM seperti COBIT, BSC, dan SSE-CMM, untuk menunjukkan bagaimana Tata Kelola Keamanan TI yang strategis dapat dirumuskan. Ini berfungsi sebagai langkah menuju penggunaan kerangka kerja dan standar yang ada untuk tujuan Tata Kelola Keamanan TI [1].

Penelitian yang dilakukan oleh Shafi Mohamad dan Mark Toomey pada tahun 2015 yang berjudul “A Survey of Information Technology Governance Capability in Five Jurisdictions Using the ISO 38500:2008 Framework". Dalam penelitian ini menjelaskan prinsip-prinsip dalam ISO 38500 tidak menentukan kepemimpinan atau keterlibatan bisnis. Namun, standar ini jelas dibingkai dengan pandangan untuk menggeser penekanan pada tata kelola TI dari kinerja teknis ke hasil bisnis. Dengan demikian, standar ini meminta keterlibatan para pemimpin bisnis, untuk mengambil tanggung jawab, untuk merumuskan rencana bisnis yang mempertimbangkan dan mendorong penggunaan TI, untuk memfokuskan investasi dalam TI pada hasil bisnis, untuk menetapkan dan mencapai target kinerja bisnis untuk TI, untuk memiliki aturan yang konsisten terkait dengan penggunaan TI yang diamati dan dihormati di seluruh organisasi, dan untuk memastikan bahwa kebutuhan, perilaku dan karakteristik lain dari komunitas manusia yang relevan dipahami dan dihormati. [2].

Dari literatur review yang telah dijelaskan diatas maka dapat diambil intisarinya bahwa prinsip-prinsip ISO 38500 membentuk komponen yang menyediakan rutinitas dan praktik kerja, sehingga memperkuat kemampuan inti keseluruhan organisasi dalam hal audit TI. 
Tabel 1. Ringkasan Review Artikel

\begin{tabular}{|c|c|c|c|c|}
\hline No. & $\begin{array}{c}\text { Pengarang, } \\
\text { Tahun, } \\
\text { Sumber }\end{array}$ & Objek & Metode & Hasil \\
\hline 1. & $\begin{array}{l}\text { Suchit Ahuja } \\
\text { dan Yolande E. } \\
\text { Chan, 2015, } \\
\text { CONF-IRM } \\
\text { Proceedings }\end{array}$ & $\begin{array}{l}\text { Tata kelola } \\
\text { keamanan TI, } \\
\text { dan } \\
\text { menunjukkan } \\
\text { solusi } \\
\text { mitigasi } \\
\text { untuk } \\
\text { tantangan } \\
\text { tata kelola } \\
\text { keamanan TI. }\end{array}$ & $\begin{array}{l}\text { ISO } 38500 \text {, } \\
\text { The ISM } \\
\text { Framework }\end{array}$ & $\begin{array}{l}\text { Menggabungkan } \\
\text { komponen ISM } \\
\text { seperti COBIT, } \\
\text { BSC, dan SSE- } \\
\text { CMM, untuk } \\
\text { menunjukkan } \\
\text { bagaimana Tata } \\
\text { Kelola } \\
\text { Keamanan TI } \\
\text { yang strategis } \\
\text { dapat } \\
\text { dirumuskan. Ini } \\
\text { berfungsi } \\
\text { sebagai langkah } \\
\text { menuju } \\
\text { penggunaan } \\
\text { kerangka kerja } \\
\text { dan standar yang } \\
\text { ada untuk tujuan } \\
\text { Tata Kelola } \\
\text { Keamanan TI. }\end{array}$ \\
\hline 2. & $\begin{array}{l}\text { Shafi Mohamad } \\
\text { dan Mark } \\
\text { Toomey, 2015, } \\
\text { International } \\
\text { Journal of } \\
\text { Disclosure and } \\
\text { Governance }\end{array}$ & $\begin{array}{l}\text { Tingkat } \\
\text { kemampuan } \\
\text { praktik tata } \\
\text { kelola TI } \\
\text { yang telah } \\
\text { dilakukan } \\
\text { negara- } \\
\text { negara } \\
\text { berkembang } \\
\text { dibandingkan } \\
\text { dengan yang } \\
\text { biasanya } \\
\text { diamati di } \\
\text { negara maju. }\end{array}$ & ISO 38500 & $\begin{array}{l}\text { Prinsip-prinsip } \\
\text { dalam ISO } \\
38500 \text { tidak } \\
\text { menentukan } \\
\text { kepemimpinan } \\
\text { atau keterlibatan } \\
\text { bisnis. Standar } \\
\text { ini jelas } \\
\text { dibingkai } \\
\text { dengan } \\
\text { pandangan } \\
\text { untuk } \\
\text { menggeser } \\
\text { penekanan pada } \\
\text { tata kelola TI } \\
\text { dari kinerja } \\
\text { teknis ke hasil } \\
\text { bisnis. }\end{array}$ \\
\hline
\end{tabular}

Standar ISO 38500 memberikan prinsip-prinsip panduan untuk direktur organisasi pada penggunaan efektif, efisien, dan dapat diterima Teknologi 
Informasi (TI) dalam organisasi. Kerangka kerja ini terdiri dari enam prinsip tata kelola perusahaan yang baik dari IT:

a. Responsibility (Tanggung jawab).

Beberapa organisasi kurang memperhatikan pekerjaan yang seharusnya bertanggung jawab daripada yang sebenarnya mereka lakukan untuk memberikan tanggung jawab, dan kemudian beberapa organisasi benarbenar memantau untuk memastikan bahwa tanggung jawab pekerjaan dikerjakan dan dipenuhi secara memadai.

b. Strategy (Strategi)

Organisasi sering melakukan upaya untuk mengevaluasi strategi dan masalah perencanaan, tetapi kemudian tidak menindaklanjuti untuk menerapkan rencana itu dan memeriksa apakah mereka benar-benar terwujud.

c. Acquisition (Akuisisi)

Level kontrol yang lebih tinggi dalam mengevaluasi opsi dan mengarahkan akuisisi dibatalkan karena kurangnya pemantauan.

d. Performance (Kinerja)

Pendekatan minimalis untuk evaluasi menimbulkan beberapa pertanyaan tentang asal-usul dan legitimasi arah yang diberikan, dan terbatasnya pemantauan yang ada dapat menimbulkan keraguan jika kesenjangan kinerja dipahami dengan baik jika memang ada.

e. Conformance (Kesesuaian)

Seringkali kinerja perusahaan mendapat skor tinggi, tetapi sekali lagi polanya adalah di mana pemantauan tidak berjalan, membuat orang bertanya-tanya apakah organisasi berisiko melanggar pelanggaran kepatuhan meskipun telah menerapkan beberapa aturan.

f. Human Behaviour (Perilaku manusia)

Pemberi nilai yang relatif tinggi tidak mengimbangi gambaran keseluruhan bahwa sebagian besar organisasi kurang memperhatikan karakteristik orang dalam proses evaluasi. 


\section{KESIMPULAN}

Ulasan ini dapat menambah wawasan mengenai audit teknologi informasi menggunakan ISO 38500. Metode ISO 38500 menjadi topik yang menarik karena pentingnya audit teknologi informasi di perusahaan. Dengan demikian, ada panduan evaluasi mulai dari tingkat sumber daya operasi TI dan mekanisme tata kelola TI strategis yang jelas dapat dibentuk. Prinsip-prinsip ISO 38500 membentuk komponen yang menyediakan rutinitas dan praktik kerja, sehingga memperkuat kemampuan inti keseluruhan organisasi dalam hal audit TI. 


\section{DAFTAR PUSTAKA}

[1] Ahuja, S., \& Chan, Y. E. (2015). IT Security Governance: A Framework based on ISO 38500. International Conference on Information Resources Management (CONF-IRM), (pp. 1-14).

[2] Mohamad, S., \& Toomey, M. (2015). A Survey of Information Technology Governance Capability in Five Jurisdictions Using the ISO 38500:2008 Framework. International Journal of Disclosure and Governance, -. doi:10.1057/jdg.2015.5 